\title{
Vegetation databases provide a close-up on altitudinal tree species distribution in the Bavarian Alps
}

\author{
Jörg Ewald
}

\begin{abstract}
Thermal limits of tree species are of paramount interest in monitoring and projecting effects of climate warming. Based on the large phytosociological database BERGWALD, a database of forest inventory plots, and phytosociological tables of vegetation above treeline, tree species occurrence along a regional elevation gradient was assessed separately for tree and regeneration layer individuals. Upper limits in the database were compared to altitudinal limits given in Oberdorfer's regional flora and to northern latitudinal limits given in worldwide distribution maps. For 26 of 32 tree species, the known distribution limits had to be raised based on plot data, demonstrating the high potential of vegetation databases to deliver ecological information. In most species, regeneration layer occurrences markedly exceeded the altitudinal limit of trees, indicating a potential for rather rapid advances of treelines under climate warming. Regional altitudinal and global latitudinal limits were quite closely related in the majority of tree species. However, several tree species climb to much higher elevation in the Alps than their latitudinal limits suggest. The boreal-subalpine mismatch in cold limits is only partly explained by vicariism and endemism. Sorbus aria, Acer pseudoplatanus, Fagus sylvatica and Taxus baccata are important elements of temperate mountain forests, which do not reach thermally equivalent northern latitudes for unknown reasons.
\end{abstract}

Keywords: cold limit; leading edge; range limit; treeline.

Abbreviations: $\mathrm{FI}=$ forest inventory; NFV = non-forest vegetation; $\mathrm{SDM}=$ species distribution model.

Received: 26 March 2010 - Accepted: 13 October 2011 - Co-ordinating editor: Jens Oldeland.

\section{Introduction}

Concerns about global warming have brought tree species back into the focus of plant ecology. Obviously, their thermal niche is of particular interest, which can be studied particularly well in mountains with a close dependence of temperature on elevation and steep temperature gradients on short distances (Körner 2007). Models of cold limits are often based on coarse scale distribution data and climate models, which perform reasonably well in high latitudes, but fail in mountains with long temperature gradients within grid cells. Thus, high resolution species observations such as individual floristic records or vegetation plots are necessary to find local and absolute cold limits in mountains. While some regional floras, such as Oberdorfer (2001), compile information on known altitudinal limits, high resolution observation records in databases have the potential of providing much more explicit information on altitudinal distribution (Guisan et al. 2007).
Owing to the tight relationship between elevation and temperature within a given mountain range, altitudinal limits provide an approximation of species' temperature limits. Comparing such local cold limits to worldwide latitudinal limits presents a test of the physiological equivalence of both.

In climate change research the cold limit of species is often regarded as the "leading edge", where pole- and upward advances are projected (Aitken et al. 2008). Like timber- and treeline, many tree species limits are fuzzy, consisting of an absolute upper limit, often represented by seedlings and low shrubby outposts, and a limit of tree-sized individuals. Outposts not reaching sexual maturity must be regarded as sink populations that depend on seed flow from treeline under present climate, but will likely be released from climatic stress by warming. Thus anticipating dispersal into warming habitats, outpost-forming tree species are crucial for the potential speed at which upward shifts of forest can take place.
In the present study, vegetation databases served to answer the following questions:

1. What are the altitudinal limits of important tree species in the Bavarian Alps?

2. How wide is the outpost zone for important tree species?

3. How do local altitudinal limits relate to worldwide latitudinal limits?

\section{Material and methods}

The Bavarian Alps represent the German portion of the Northern Alps, comprising several chains of east-west oriented mountain ranges. Average annual temperatures $\left(8.2\right.$ to $\left.-3.0^{\circ} \mathrm{C}\right)$ are closely

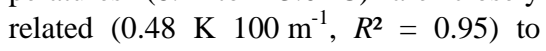
elevation (470 to 2,976 $\mathrm{m}$ a.s.1.).

Altitudinal distribution data were derived from the following sources: The phytosociological flora by Oberdorfer (2001) mentions maximum elevation for many species, which was based on longlasting, but informal literature review, 
personal observations and communication with experts (A. Schwabe, pers. comm.). BERGWALD is a database of forest and related vegetation in the Bavarian Alps (Ewald 1995, 2012) and, at the time of study, contained 4,934 relevés (95.5\% with original elevation information) from 52 sources. $85 \%$ of relevés originated in projects with preferential sampling, usually geared at optimal coverage of community variation within study areas, $2 \%$ from stratified random sampling with elevation as a criterion for placement.

Hiebl (2010) analysed 62,901 georeferenced forest inventory (FI) plots from Bavarian state forests, which make up $50 \%$ of the Bavarian Alps, by courtesy of the Bavarian State Forest Institution (BaySF). FI is a systematic grid sample (Klemmt 2007), but does not cover treeless areas above timberline.

Since BERGWALD and FI focus on forests, the vegetation tables in Rehder (1970), Spatz (1970), Herter (1990), Lang (1991), Eggensberger (1994), Rösler (1997) and Zednik (1997) were systematically screened for records of tree regeneration in non-forest vegetation (NFV) above tree line. These relevés were placed preferentially without focus on the occurrence of tree species, which were documented as a by-product of complete species lists.

Tree layer $(>5 \mathrm{~m})$ records in BERGWALD were queried separately from shrub and field layers, which were combined as regeneration. Boxplots representing the distribution of tree and regeneration observations across the elevation gradient were plotted for all species with more than 50 occurrences in the BERGWALD database. All relevés with maximum elevation of tree species were checked for credibility. Maxima from FI (Hiebl 2010) and other sources were combined in a table, yielding absolute limits for the Bavarian Alps. Rank correlation between average elevation from BERGWALD, observed maximum elevation of occurrence and tree species' Ellenberg indicator value for temperature (Ellenberg et al. 2001) was quantified by the Spearman coefficient (Pearson's correlation coefficient between ranks).

Latitudinal limits (decimal degrees) were queried in ArcGIS from up-to-date shapefiles of worldwide distribution, obtained from the University of Halle (Welk et al. 2010), and plotted against absolute altitudinal limits. Indicator values for temperature were taken from Ellenberg et al. (2001), modes of seed

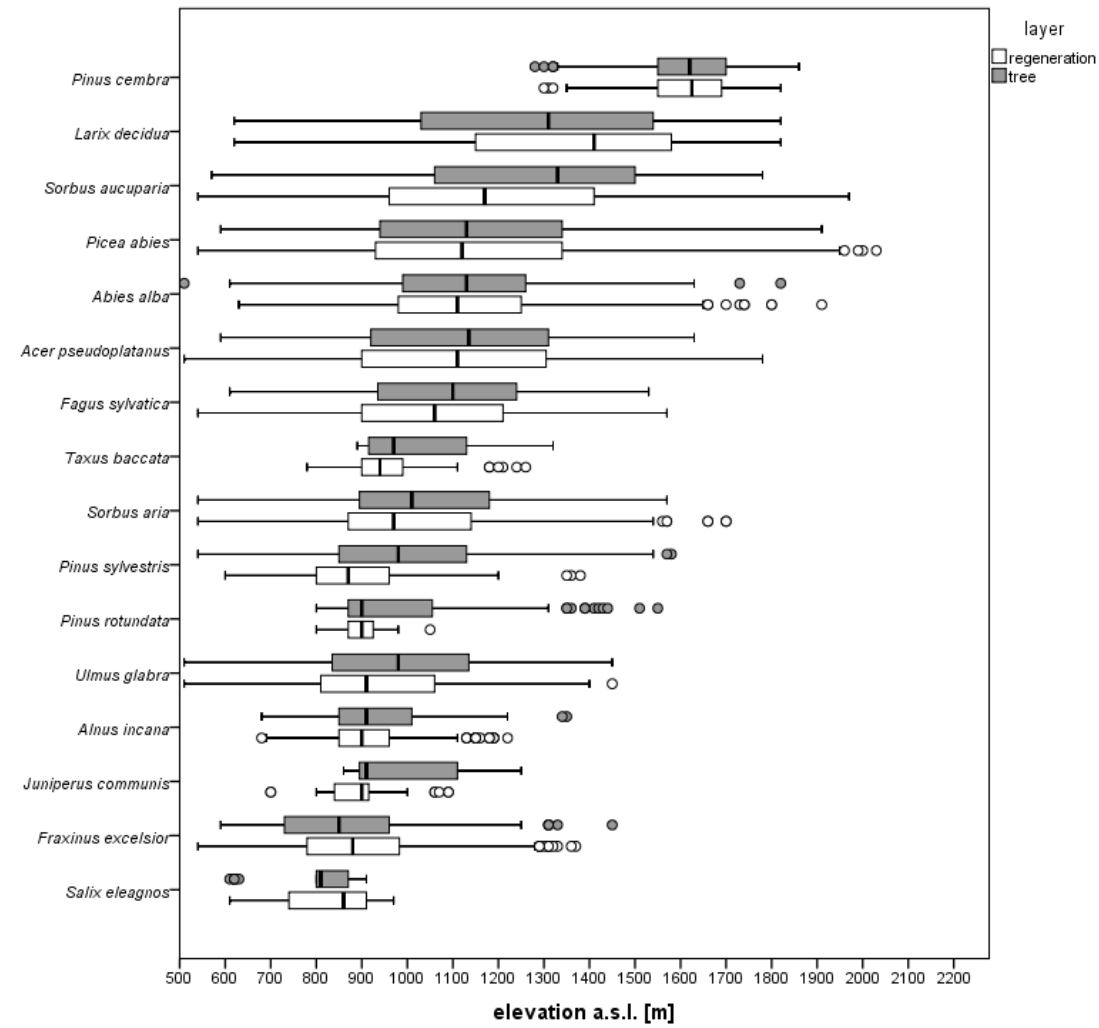

Fig. 1: Boxplots of altitudinal distribution of common tree species (constancy $>1 \%$ ) in the Bavarian Alps based on the BERGWALD database; tree species ranked by mean elevation.

dispersal were taken from Jäger \& Werner (2005).

\section{Results}

According to the combined content of the vegetation databases 32 tree species occurred in the study region (Table 1). BERGWALD yielded elevation data on 29, Oberdorfer on 27, non-forest relevés on 23 and FI on 13 tree species. Delivery of absolute elevation maxima followed the same order, with 14 tree species by BERGWALD, 12 by Oberdorfer, 4 by non-forest relevés and 2 by FI. Oberdorfer's maxima were exceeded for all common tree species (constancy > 20\%) except Sorbus aucuparia, mostly based on the search in non-forest relevés. The BERGWALD database delivered numerous new maxima for tree species of intermediate and low constancy. Based on FI, the maxima for Pinus sylvestris and Quercus robur could be raised.

Altitudinal distribution of the 16 tree species recorded in at least 50 relevés $(>1 \%)$ of the BERGWALD database is displayed as a boxplot ordered by decreasing average elevation of occurrence (Fig. 1). Species differed mostly in the extent to which they occur at high altitudes, while almost all had occurrences down to the valley bottoms. Pinus cembra was the only tree species strictly restricted to high altitudes above $1,200 \mathrm{~m}$ a.s.l. (Plate A). There was a great variety of distribution types regarding the relationship between tree and regeneration layer. For the majority of species median elevation was higher for trees than for regeneration, with the notable exception of Larix decidua, Fraxinus excelsior and Salix eleagnos (Fig. 2). Thus, common tree species like Fagus sylvatica occur as dwarf or krummholz forms at orographic timberlines (Plate B). As indicated by the absence of values outside the whiskers (1.5 of the box length), occurrences were evenly distributed across the elevation range in many species. Extreme outliers at the high end existed for Picea abies, Abies alba, Taxus baccata, Sorbus aria, Pinus rotundata, Alnus incana and Fraxinus excelsior. Upper limits were generally similar for tree and regeneration layer. Several regeneration outposts beyond the highest trees were detected for Sorbus aucuparia, Acer pseudoplatanus and Picea abies.

Maximum elevation of occurrence was closely related to average elevation 
(Spearman $\rho=0.72$ ). Ellenberg temperature values of 21 tree species were more closely related to average $(\rho=-0.71)$ than to maximum elevation $(\rho=-0.63)$.

Maximum elevation in the regeneration layer usually exceeded the maximum for tree layer occurrences with the exception of Ulmus glabra and Alnus incana (Fig. 3). Pinus sylvestris, Fraxinus excelsior and Pinus cembra had tree maxima up to $100 \mathrm{~m}$ beyond the highest observed regeneration.

With wind- (Acer pseudoplata nus, Salix eleagnos) as well as bird-dispersed trees (Taxus baccata, Fagus sylvatica) among the outpost-forming species, there was no obvious pattern of dispersal modes (Tab. 1) associated with the advance of shrub outposts above trees.

Northern limits were obtained from shape files of world-wide distribution data for 29 tree species (Welk et al. 2010, without synanthropic distribution) and plotted against overall maximum elevation in the Bavarian Alps (Fig. 3). Northern limits of high boreal tree species appeared to be confined by the northern limit of continental land mass at $71^{\circ}$ latitude. For species reaching limits at lower latitudes, Ulmus glabra, Alnus glutinosa, Tilia cordata, Quercus robur, Acer platanoides and Tilia platyphyllos, the relationship between altitudinal and latitudinal limits appeared to be linear. However, all but Ulmus were restricted to the lowest elevations of the Alps and thus represented by only few observations. A third group of tree species (Fraxinus excelsior, Prunus avium, Taxus baccata, Salix daphnoides and Fagus sylvatica) reached relatively high elevations in the Alps, but extended only to the southern, hemiboreal parts of Scandinavia between 60 and $65^{\circ}$ northern latitude. The remaining tree species are typical of the Alps and other high mountain ranges, but are practically absent from Northern Europe. Within the group, three biogeographical categories may be discerned: Acer pseudoplatanus and Sorbus aria extend to the Central and Western European lowlands and have no sister taxa in the boreal flora; Larix decidua and Pinus cembra have vicariant sister taxa in boreal Siberia (A., L. and P. sibirica); and Abies alba, Pinus rotundata, $P$. uncinata and Salix eleagnos are endemics of Central and Southern European mountain ranges.

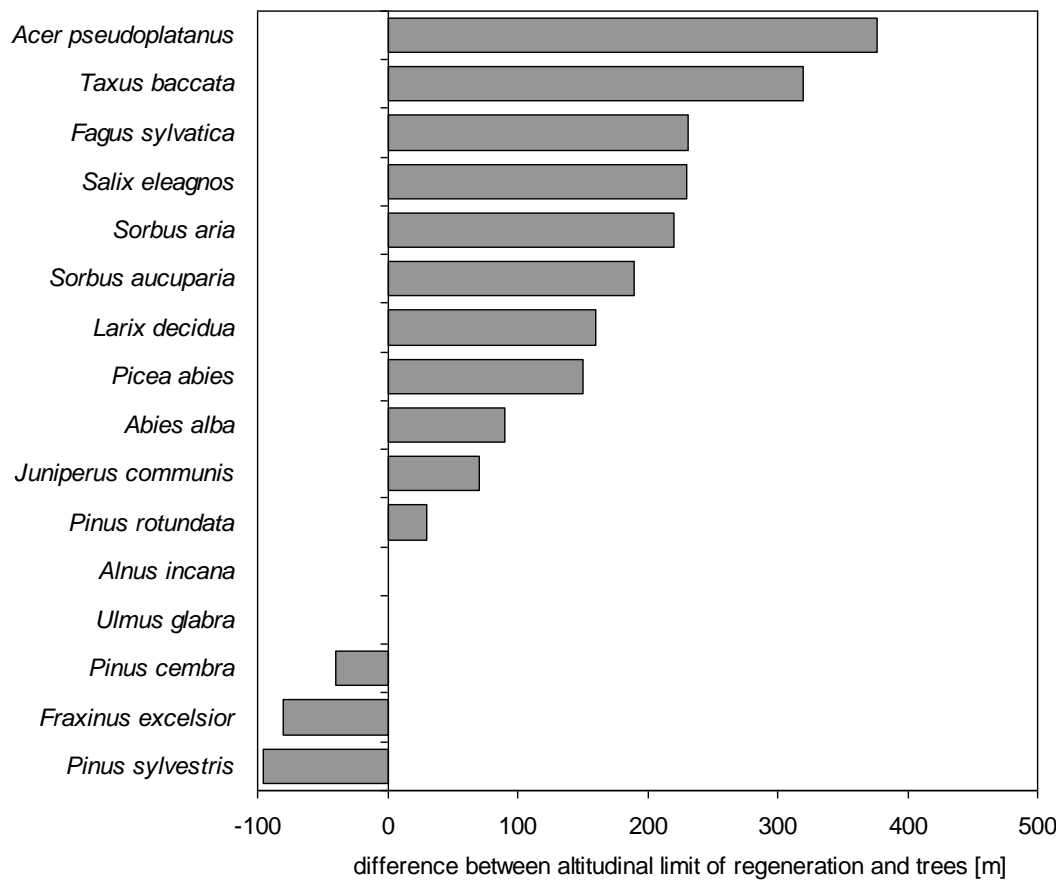

Fig. 2: Differences between elevation maximum of regeneration (based on BERGWALD and non-forest vegetation tables) and of trees (based on BERGWALD and forest inventory) for more common tree species (>1\% constancy in BERGW ALD database).

\section{Discussion}

Ranking tree species by their mean elevation in the BERGWALD database, the sequence Pinus cembra-Larix-PiceaAbies-Fagus-Quercus reveals perfect correspondence with the definitions of altitudinal belts by Ewald (1997), and verifies the local applicability of Ellenberg temperature values. The prominence of Acer pseudoplatanus at the upper limit of the Fagus belt conforms to the concept of "subalpine beech woods with Acer" (annex I type 9140 of the EU habitats directive, Anon. 1992). On the other hand, Ulmus glabra, a name-giving tree of the "subalpine" association Ulmo-Aceretum (Clot 1990), is distributed at lower elevations. The preference of Pinus sylvestris, $P$. rotundata, Alnus incana, and Juniperus communis towards lower elevations must be attributed to the frequency of primary successions due to fluvial morphodynamics (Hölzel 1994) and of mires in alpine valleys (Ellenberg 1988), which confounds the altitudinal temperature gradient.

Tree species distribution is usually limited by low temperatures and short growing season at high altitudes. The occurrence of subalpine specialists like Larix decidua and Sorbus aucuparia in early successional habitats at low elevation indicates that their lower limits are caused by competition rather than physiological constraints. Viewed against this finding, the unique distribution of Pinus cembra invokes biotic interactions like missing mycorrhizal partners (Kernaghan et al. 1997) or cold-intolerant pathogens. Narrowly confined to few of the highest massives, the distribution of $P$. cembra in the Northern Calcareous Alps appears as a relic of colder periods and suggests high regional extinction risk under climate warming.

In a densely populated and well-studied region like Central Europe, one might assume that altitudinal limits of tree species are well-known, and documented in handbooks like Oberdorfer's (2001). Early knowledge about altitudinal limits (Sendtner 1854, Kerner von Marilaun 1896, Rubner 1925) seems to have sedimented into silviculture and botany textbooks without much updating and refinement. Apparently, before the climate change debate, the study of tree species distributions was considered unrewarding. The present study demonstrates the value of high resolution observation databases in obtaining more explicit and exact information (Ewald 2001, Guisan et al. 2007, Lenoir et al. 2009, Dengler et al. 2011) in four respects: (1) Maxima can be considerably corrected; (2) frequency 
along the altitudinal gradient can be studied; (3) tree and regeneration occurrences can be discerned from layer information; and (4) plot locations can be intersected with spatially interpolated climate variables or re-visited for field measurements.

Depending on the underlying sampling strategy, the sources differ in their potential to find upper limits of trees. The BERGWALD database contains a majority of preferentially sampled plots placed in forests of all types, including high elevation forests and krummholz around timberline. Representing tree species proportional to their frequency and missing treeless vegetation, FI data are less effective in finding upper limits despite the large sample size. Relevés from nonforest vegetation demonstrate the usefulness of complete species sampling beyond the proximate goal of vegetation studies, as pointed out by Ewald (2001, 2003). Observation of tree seedlings in alpine vegetation is a useful by-product, which allows assessing the limits of longdistance seed dispersal of common species with high seed pressure.

For most species, shrubs, saplings and seedlings reach way beyond the upper limit of the tree growth form. If we assume that sexual reproduction will usually not take place before heights of $5 \mathrm{~m}$ are reached, regeneration outposts have to be regarded as sink populations, which rely on seed flow from populations at the respective tree limit (Pulliam 1988, Dias 1996). Unfortunately, the demographic information in vegetation and forest inventory data is limited, and does not allow a clear distinction between seedlings, which merely indicate the range of seed dispersal, and established saplings. An altitudinal advance of saplings over trees has been shown in the Scandes (Hofgaard et al. 2009), where advanced sapling occurrences were attributed a key role in treeline response to warming climate. Woodall et al. (2009) found significant northward advances of saplings over trees in boreal species of North America. The fact that Lenoir et al. (2009) found only insignificant advances of seedlings at upper limits in French mountains is attributable to the exclusion of plots in the treeline ecotone. The finding of these authors that seedlings have significantly higher low elevation limits than trees is not visible in the Bavarian Alps, giving no sign of range contraction induced by recent warming.

Table 1: Maximum elevation of occurrence $[\mathrm{m}]$ in the Bavarian Alps for 32 tree species according to the following sources: Oberdorfer (2001), database BERGWALD, forest inventory (FI) and non-forest vegetation tables (NFV); known maximum elevation in bold; northern latitudinal limit from shapefiles (dots and northern bounds of polygons) provided by Welk et al. (2010); T: indicator values for temperature from Ellenberg et al. (2001); dispersal mode from Jäger \& Werner (2005): w: wind, g: gut, h: hiding places.

\begin{tabular}{|c|c|c|c|c|c|c|c|c|c|c|c|c|c|c|c|}
\hline \multirow[t]{2}{*}{ Species } & \multirow[t]{2}{*}{$\begin{array}{l}\text { Oberd. } \\
\max \end{array}$} & \multicolumn{3}{|c|}{$\begin{array}{l}\text { BERGWALD } \\
\text { constancy \% }\end{array}$} & $\max$ & & & \multirow[t]{2}{*}{$\begin{array}{c}\mathrm{FI} \\
\max \end{array}$} & \multirow[t]{2}{*}{$\begin{array}{l}\mathrm{NFV} \\
\max \end{array}$} & \multirow[t]{2}{*}{$\begin{array}{l}\text { All } \\
\max \end{array}$} & \multirow[t]{2}{*}{ Reference of $\max$} & \multicolumn{2}{|c|}{$\begin{array}{c}\text { GIS } \\
\text { max N latitude }\end{array}$} & \multirow{2}{*}{\multicolumn{2}{|c|}{$\begin{array}{cc}\text { Dispersal } \\
\text { T } & \text { mode }\end{array}$}} \\
\hline & & total & tree & reg & total & tree & reg & & & & & total dots & polygon & & \\
\hline Picea abies & 1900 & 83.7 & 69.6 & 61.3 & 2030 & 1910 & 2030 & 1856 & 2060 & 2060 & Rösler (1997) & 69.7969 .79 & 69.25 & 3 & w \\
\hline Acer pseudoplatanus & 1640 & 63 & 25.5 & 58.3 & 1780 & 1630 & 1780 & 1653 & 2030 & 2030 & Eggensberger (1994) & 54.6354 .63 & 54.44 & & w \\
\hline Sorbus aucuparia & 1980 & 51.5 & 3.9 & 50.5 & 1970 & 1780 & 1970 & 1660 & 1940 & 1980 & Oberdorfer (2001) & 71.1668 .26 & 71.16 & & $\mathrm{~g}$ \\
\hline Fagus sylvatica & 1500 & 45.8 & 34.1 & 37.0 & 1570 & 1530 & 1570 & 1539 & 1770 & 1770 & Eggensberger (1994) & 60.6660 .66 & 60.33 & 5 & $\mathrm{~h}$ \\
\hline Abies alba & 1560 & 36.2 & 23.6 & 28.3 & 1910 & 1820 & 1910 & 1750 & 1740 & 1910 & Frankl (2001) & 52.3152 .31 & 52.13 & 3 & w \\
\hline Sorbus aria & 1560 & 25.2 & 5.5 & 23.1 & 1700 & 1570 & 1700 & 1525 & 1790 & 1790 & Michiels (1992) & 53.8553 .85 & 52.19 & 5 & g \\
\hline Fraxinus excelsior & & 16 & 4.7 & 14.7 & 1450 & 1450 & 1370 & 1363 & 1280 & 1450 & Feldner (1978) & 64.0164 .01 & 61.53 & 5 & w \\
\hline Larix decidua & 2003 & 14 & 11.9 & 5.6 & 1820 & 1820 & 1820 & 1753 & 1980 & 2003 & Oberdorfer (2001) & 50.5546 .82 & 50.55 & & w \\
\hline Pinus sylvestris & 1600 & 9.7 & 8.4 & 2.9 & 1580 & 1580 & 1540 & 1636 & 1260 & 1636 & Hiebl (2010) & 70.1067 .81 & 70.10 & & w \\
\hline Ulmus glabra & 1380 & 7.7 & 3.8 & 5.5 & 1450 & 1450 & 1450 & 1349 & 1190 & 1450 & Feldner (1978) & 67.0967 .09 & 60.82 & 5 & w \\
\hline Alnus incana & 1400 & 5.2 & 3.3 & 4.6 & 1350 & 1350 & 1350 & & 1150 & 1400 & Oberdorfer (2001) & 70.7570 .75 & 70.54 & 4 & w \\
\hline Pinus cembra & 1960 & 3.9 & 3.7 & 2.0 & 1860 & 1860 & 1820 & 1776 & 1240 & 1960 & Oberdorfer (2001) & 49.3049 .30 & 49.28 & 2 & $\mathrm{~h}$ \\
\hline Pinus rotundata & & 2.7 & 2.1 & 1.6 & 1580 & 1550 & 1580 & & & $1580 \mathrm{~L}$ & Lorenz (1993) & 50.8450 .84 & 46.24 & 3 & w \\
\hline Salix eleagnos & 1300 & 1.8 & 0.5 & 1.5 & 970 & 910 & 970 & & 1140 & 1300 & Oberdorfer (2001) & 50.0050 .00 & 49.84 & 5 & w \\
\hline Taxus baccata & 1400 & 1.5 & 0.7 & 1.1 & 1640 & 1320 & 1640 & 1177 & & $1640 \mathrm{I}$ & Michiels (1992) & 62.7262 .72 & 55.60 & 5 & $g$ \\
\hline Juniperus communis & 1600 & 1.4 & 0.2 & 1.3 & 1320 & 1250 & 1320 & & & 1600 & Oberdorfer (2001) & & & & g \\
\hline Betula pendula & 1780 & 0.9 & 0.4 & 0.5 & 1310 & 1310 & 1150 & & 1060 & 1780 & Oberdorfer (2001) & 69.9069 .48 & 69.90 & & w \\
\hline Acer platanoides & 1060 & 0.7 & 0.2 & 0.6 & 1170 & 1110 & 1170 & & 860 & 1170 & Ewald (1997) & 63.2362 .88 & 63.23 & & w \\
\hline Tilia platyphyllos & 1000 & 0.6 & 0.4 & 0.5 & 1010 & 1010 & 1010 & & 820 & 1010 & Feldner (1978) & 59.1259 .12 & 52.26 & 6 & w \\
\hline Betula pubescens & 1580 & 0.5 & 0.2 & 0.3 & 1660 & 1660 & 1570 & & 1530 & 1660 & Feldner (1978) & 70.3668 .20 & 70.36 & & w \\
\hline Salix caprea & 1730 & 0.5 & 0.1 & 0.5 & 1450 & 1090 & 1450 & & 1270 & 1730 & Oberdorfer (2001) & 70.6770 .67 & 70.39 & & w \\
\hline Prunus padus & 1500 & 0.4 & 0.1 & 0.5 & 950 & 860 & 950 & & 870 & 1500 & Oberdorfer (2001) & 71.1668 .88 & 71.16 & 5 & $g$ \\
\hline Alnus glutinosa & 1030 & 0.4 & 0.4 & 0.3 & 1140 & 1050 & 1140 & & & $1140 \leqq$ & Storch (1983) & 66.6666 .66 & 64.52 & 5 & w \\
\hline Prunus avium & 1700 & 0.4 & 0.1 & 0.4 & 1140 & 1030 & 1140 & & & 1700 & Oberdorfer (2001) & 63.7563 .75 & 60.34 & 5 & g \\
\hline Betula carpatica & & 0.2 & 0.2 & 0.1 & 1630 & 1630 & 1510 & & & 1630 & Freiberg (1980) & & & 4 & w \\
\hline Salix daphnoides & 1300 & 0.2 & 0.1 & 0.2 & 1450 & 900 & 1450 & & 1450 & 1450 & Herter (1990) & 62.3562 .35 & & & w \\
\hline Pinus uncinata & & 0.1 & 0.1 & 0.0 & 1440 & 1440 & 820 & & & 1440 & Frankl (2001) & 50.8450 .84 & 46.24 & & $w$ \\
\hline Populus tremula & 1300 & 0.1 & 0.0 & 0.1 & 1170 & 1170 & 1030 & & 1210 & 1300 & Oberdorfer (2001) & 70.9870 .98 & 70.86 & 5 & w \\
\hline Tilia cordata & 1360 & 0.1 & 0.1 & 0.0 & 920 & 710 & 920 & & 740 & 1360 & Oberdorfer (2001) & 65.5065 .50 & 63.69 & 5 & w \\
\hline Acer campestre & 800 & 0.0 & 0.0 & 0.0 & 860 & 860 & & & & 860 & Feldner (1978) & 55.8155 .81 & & 6 & w \\
\hline Populus $\times$ canescens & & 0.0 & 0.0 & 0.0 & 900 & 900 & 900 & & & 900 & Feldner (1978) & & & & w \\
\hline Quercus robur & 950 & 0.0 & 0.0 & 0.0 & & & & 1084 & 890 & 1084 & Hiebl (2010) & 63.7963 .79 & 60.76 & 6 & $\mathrm{~h}$ \\
\hline
\end{tabular}


On the other hand, high elevation tree populations without regeneration can be interpreted as relics of a more favourable past, which have ceased to produce seeds or do no longer find safe sites for establishment (Pigott 1992). If at all, this hypothesis applies to Pinus cembra and Fraxinus excelsior in the Bavarian Alps the possible confounding of juveniles with Pinus mugo agg. commands caution in the case of Pinus sylvestris. For Pinus cembra, the absence of high elevation outposts adds another precarious aspect to the relic status of Bavarian populations.

The cold niche margin can be studied at altitudinal and latitudinal limits of tree species. Under climate warming these margins become the leading edge, where new potential habitats arise (Kullman 2009, Harsh et al. 2009). However, due to the coarse resolution of distribution and climate data, recent SDMs have devoted more attention to the northern margin (Sykes et al. 1996) than to temperate mountains with their fine-grained altitudinal gradients (Randin et al. 2009). In order to yield reliable scenarios, SDMs must reflect the physiological constraints at both types of cold margin (Cogbill \& White 1991, Normand et al. 2009). The comparison between northern and local altitudinal limits in the Bavarian Alps reveals four patterns: (1) The correlation for the majority of tree species suggests corresponding effects of temperature. (2) The limits of cold-tolerant boreal species can be better differentiated in the Alps than in the North, where they are bounded by the Arctic Ocean. (3) The comparison is obviously meaningless for alpine endemites (Pinus mugo agg., Salix eleag$n o s)$ and species with Siberian vicariants (Pinus and Larix sibirica); as a species restricted to the larger area of Central and Southern European mountains, Abies alba is transitional to the next category. (4) Fagus sylvatica and Acer pseudoplatanus, as the most frequent shade-tolerant deciduous trees of Bavarian mountain forests, as well as Sorbus aria, Taxus baccata and Prunus avium ascend to much higher elevations in the Alps than might be expected in view of their northern limits.
In Central European mountains, the tree form of Fagus sylvatica reaches a conspicuous limit at $4{ }^{\circ} \mathrm{C}$ mean annual temperature, which prevails far beyond the northern distribution limit, e.g. in Southern Finland. Rubner (1925) pointed out that Fagus and several other deciduous species do not extend into eastern, continental regions, which he attributed to the frequency of late frost. Eastern boreal Europe and Siberia experience less precipitation and radiation than the Alps, as well as strong contrasts between winter and summer temperatures and an abrupt onset of the vegetation period, which exposes young shoots to frost damage. On the other hand, the limited northwestern distributions of Fagus and Acer pseudoplatanus do not fit in well with the continentality hypothesis and invoke incomplete range filling due to migration barriers (Svenning \& Skov 2004). To account for such patterns, SDMs must be improved by increasing the spatial resolution of distribution and climate data and by including models of spring and late summer frost (Scheifinger et al. 2003).

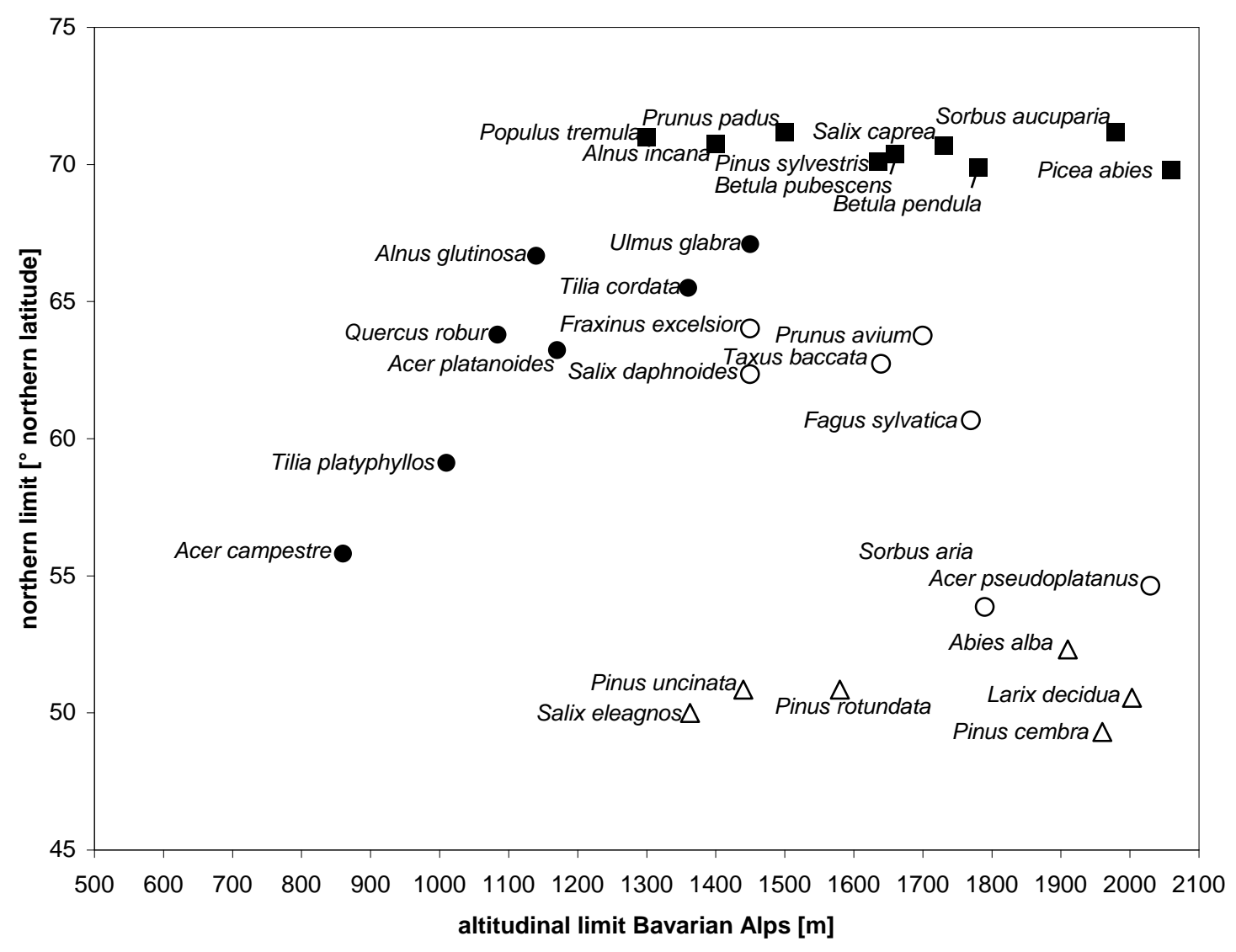

Fig. 3: Juxtaposition of altitudinal limit in the Bavarian Alps and world-wide latitudinal limit (based on data by Welk et al. 2010); -: species with rough correspondence between alpine and boreal limit; $n$ : species reaching shore of arctic sea; $\Delta$ : endemics of temperate mountains; $\circ$ : species with unexplained mismatch. 


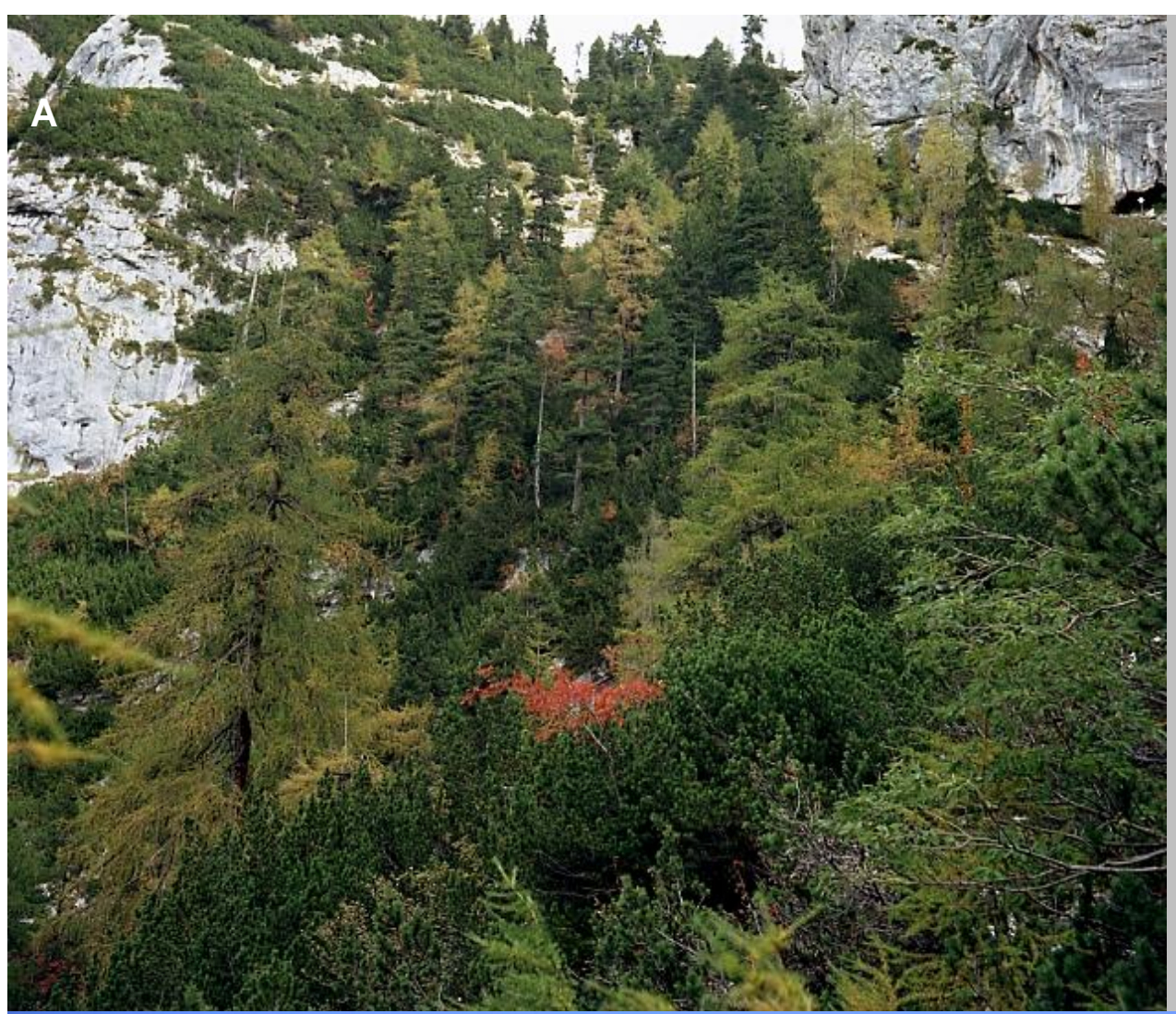

Plate:

A: Pinus cembra typically occurs in open stands at timberline, here mixed with Larix decidua and Picea abies with a shrublayer of Pinus mugo and Sorbus aucuparia; Reiter Alm near Schneitzelreuth, Bavaria (Photo: J. Ewald).

B: Orographic timberline with krummholz stands of Pinus mugo and Fagus sylvatica shaped by moving snow; Kaisergebirge near Kufstein, Austria (Photo: J. Ewald).

B

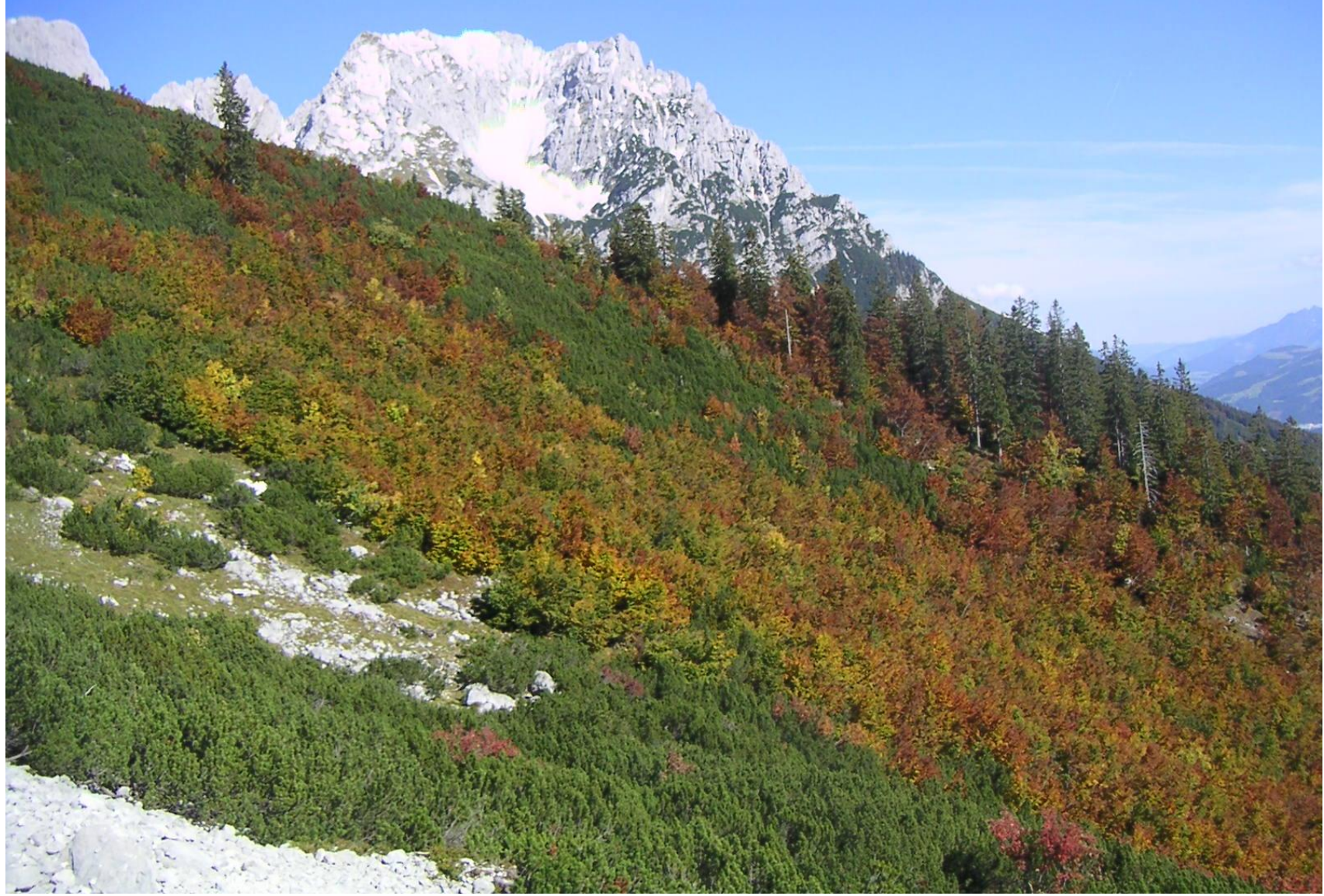




\section{Acknowledgements}

I am indebted to all authors who contributed relevés to the BERGWALD database and to the Bavarian State Forest Institution for providing access to forest inventory data. The research was generously funded under the project WINALP (www.winalp.info) by the European Fund for Regional Development (EFRE), the Bavarian Ministry for Nutrition, Agriculture and Forestry and the Bavarian State Forest Institution (BaySF). Birgit Reger, Christian Kölling, Erik Welk and Christian Rixen provided helpful reviews of the manuscript.

\section{References}

Anonymous (1992): Council directive 92/43/EEC (1) of 21 May 1992 on the conservation of natural habitats and of wild fauna and flora. - Brussels.

Aitken, S.N., Yeaman, S., Holliday, J.A., Wang, T., Curtis-McLane, S. (2008): Adaptation, migration or extirpation: climate change outcomes for tree populations. - Evolutionary Applications 1: 95111. CrossRef

Clot, F. (1990): Les érablaies européennes: essai de synthèse. - Phytocoenologia 18: 409-564.

Cogbill, C.V., White, P.S. (1991): The latitude-elevation relationship for sprucefir forest and treeline along the Appalachian mountain chain. - Plant Ecology 94: 153-175. CrossRef

Dengler, J., Jansen, F., Glöckler, F., Peet, R. K., De Cáceres, M., Chytrý, M., Ewald, J., Oldeland, J., Finckh, M., Lopez-Gonzalez, G., Mucina, L., Rodwell, J. S., Schaminée, J. H. J., Spencer, N. (2011): The Global Index of VegetationPlot Databases (GIVD): a new resource for vegetation science. - Journal of Vegetation Science 22: 582-597. CrossRef

Dias, P.C. (1996): Sources and sinks in population biology. - Trends in Ecology \& Evolution 11: 326-330. CrossRef

Eggensberger, P. (1994): Die Pflanzengesellschaften der subalpinen und alpinen Stufe der Ammergauer Alpen und ihre Stellung in den Ostalpen. - Berichte der Bayerischen Botanischen Gesellschaft Beihefte 8: 3-239.

Ellenberg, H. (1988): Vegetation ecology of Central Europe. - Cambridge University Press, Cambridge.

Ellenberg, H., Weber, H. E., Düll, R., Wirth, V., Werner, W. (2001): Zeigerwerte von Pflanzen in Mitteleuropa. - Scripta Geobotanica 18. Göttingen: Goltze.

Ewald, J. (1995): Eine vegetationskundliche Datenbank bayerischer Bergwälder.

- Hoppea, Denkschriften der
Regensburgischen Botanischen Gesellschaft 56: 453-465.

Ewald, J. (1997): Die Bergmischwälder der Bayerischen Alpen - Soziologie, Standortbindung und Verbreitung. Dissertationes Botanicae 209. Berlin: Cramer.

Ewald, J. (2001): Der Beitrag pflanzensoziologischer Datenbanken zur vegetationsökologischen Forschung. - Berichte der Reinhold-Tüxen-Gesellschaft 13: 53-69.

Ewald, J. (2003): A critique for phytosociology. - Journal of Vegetation Science 14: 291-296. CrossRef

Ewald, J. (2012): BERGWALD - the vegetation database of mountain forests in the Bavarian Alps. - In: Dengler, J., Oldeland, J., Jansen, F., Chytrý, M., Ewald, J., Finckh, M., Glöckler, F., Lopez-Gonzalez, G., Peet, R.K., Schaminée, J.H.J. (2012) [Eds.]: Vegetation databases for the 21st century. - Biodiversity \& Ecology 4: 161-165. Hamburg: Biocentre Klein Flottbek and Botanical Garden CrossRef

Feldner, R (1978): Waldgesellschaften, Wald- und Forstgeschichte und Schlußfolgerungen für die waldbauliche Planung im N.S.G. Ammergauer Berge. $\mathrm{PhD}$ thesis, Universität für Bodenkultur, Vienna.

Frankl, R. (2001): Die Bergkiefer (Pinus mugo Turra) in den Tannheimer Bergen - ein Beitrag zur Kenntnis nordalpiner Latschengebüsche. - Berichte der Bayerischen Botanischen Gesellschaft 71: 123-158.

Guisan, A., Spehn, E., Körner, C. (2007): MRI Newsletter 8: Georeferenced biological databases - a tool for understanding mountain biodiversity. - Mountain Research and Development 27: 8081. CrossRef

Harsh, M.A., Hulme, P.E., McGlone, M.S., Duncan, R.P. (2009): Are treelines advancing? A global meta-analysis of treeline response to climate warming. Ecology Letters 12: 1040-1049.

Hiebl, W. (2010): Regionalspezifische Analyse der Baumartenzusammensetzung im Bayerischen Alpenraum anhand von Forstinventurdaten. - Diploma Thesis, Hochschule WeihenstephanTriesdorf, Freising.

Hölzel, N. (1994): SchneeheideKiefernwälder in den mittleren Nördlichen Kalkalpen. - PhD thesis, LudwigMaximilians-Universität, Munich.

Hofgaard, A., Dalen, L., Hytteborn, $\mathrm{H}$. (2009): Tree recruitment above the treeline and potential for climate-driven treeline change. - Journal of Vegetation Science 20: 1133-1144. CrossRef

Jäger, E.J., Werner, K. (2005) [Eds.]: Gefäßpflanzen: Kritischer Band. - In: Rothmaler, W. [Founder]: Exkursionsflora von Deutschland 4. 10th ed. - München: Elsevier.
Kernaghan, G., Currah R.S., Bayer, R.J. (1997): Russulaceous ectomycorrhizae of Abies lasiocarpa and Picea engelmannii. - Canadian Journal of Botany 75: 1843-1850. CrossRef

Kerner von Marilaun, A. (1896): The natural history of plants 2. - New York: Hult.

Klemmt, H.-J. (2007): Standortabhängige Ableitung der Höhenwuchsleistung aus Forstinventurdaten mit Hilfe von DataMining-Methoden. Grundlage für die regionale, standortbezogene Feinjustierung des forstlichen Wuchsmodells SILVA. - PhD thesis, Technische Universität München, Freising.

Körner, C. (2007): The use of 'altitude' in ecological research. - Trends in Ecology \& Evolution 22: 569-574.

Kullman, L. (2009): Thermophilic tree species reinvade subalpine Sweden early responses to anomalous late holocene climate warming. - Arctic, Antarctic, and Alpine Research 40: 104-110. CrossRef

Lenoir, J., Gégout, J.-C., Pierrat, J.-C., Bontemps, J.-D., Dhôte, J.-F. (2009): Differences between tree species seedling and adult altitudinal distribution in mountain forests during the recent warm period (1986-2006). - Ecography 32: 765-777. CrossRef

Michiels, H. (1993): Die Stellung einiger Baum- und Straucharten in der Struktur und Dynamik der Vegetation im Bereich der hochmontanen und subalpinen Waldstufe der Bayerischen Kalkalpen. Forstliche Forschungsberichte 135. München.

Normand, S., Treier, U.A., Randin, C., Vittoz, P., Guisan, A., Svenning, J.-C. (2009): Importance of abiotic stress as a range-limit determinant for European plants: insights from species responses to climatic gradients. - Global Ecology and Biogeography 18: 437-449. Cross$\underline{\text { Ref }}$

Oberdorfer, E. (2001): Pflanzensoziologische Exkursionsflora für Deutschland und angrenzende Gebiete. - Stuttgart: Ulmer.

Pigott, C.D. (1992): Are the distributions of tree species determined by failure to set seed? - In: Marshall, C., Grace, J. [Eds.]: Fruit and seed production - aspects of development, environmental physiology and ecology: 203-215. Cambridge: Cambridge University Press.

Pulliam, H.R. (1988): Sources, sinks, and population regulation. - American Naturalist 132: 652-661. CrossRef

Randin, C.F., Engler, R., Normand, S., Zappa, M., Zimmermann, N.E., Pearman, P.B., Vittoz, P., Thuiller, W., Guisan, A. (2009): Climate change and plant distribution: local models predict high-elevation persistence. - Global Change Biology 15: 1557-1569. Cross$\underline{\text { Ref }}$

Rösler, S. (1997): Die Rasengesellschaften der Klasse Seslerietea in den Baye- 
rischen Alpen und ihre Verzahnung mit dem Carlino-Caricetum sempervirentis (Klasse Festuco-Brometea). - Hoppea, Denkschriften der Regensburgischen Botanischen Gesellschaft 58: 5-216.

Rubner, K. (1925): Die pflanzengeographischen Grundlagen des Waldbaus, 2nd ed. - Neudamm: J. Neumann.

Scheifinger, H., Menzel, A., Koch, E., Peter, Ch. (2003): Trends of spring time frost events and phenological dates in Central Europe. - Theoretical and Applied Climatology 74: 41-51. CrossRef Sendtner, O. (1854): Die Vegetationsverhältnisse Südbayerns nach den Grundsätzen der Pflanzengeographie und mit
Bezugnahme auf die Landeskultur. München: Literarisch-artistische Anstalt.

Svenning, J.-C., Skov, F. (2004): Limited filling of the potential range in European tree species. - Ecology Letters 7: 565573. $\underline{\text { CrossRef }}$

Sykes, M.T., Prentice, C., Cramer, W. (1996): A bioclimatic model for the potential distributions of north European tree species under present and future climates. - Journal of Biogeography 23: 203-233.

Welk, E., Katterfeld, C., Seidler, G. (2010): Forschungsprojekt klimatische Modellierung von Pflanzenarealen. - URL: http://www2.biologie.uni-halle.de/bot/ag chorologie/areale/ [accessed on 201004-22].

Woodall, C.W., Oswalt, C.M., Westfall, J.A., Perry, C.H., Nelson, M.D., Finley, A.O. (2009): An indicator of tree migration in forests of the eastern United States. - Forest Ecology and Management 257: 1434-1444. CrossRef

Jörg Ewald (joerg.ewald@hswt.de) University of Applied Sciences Weihenstephan-Triesdorf Hans-Carl-von-Carlowitz-Platz 3 85354 Freising, GERMANY 